\title{
Erratum to: Functional properties of protein hydrolysates from different body parts of horse mackerel (Magalaspis cordyla) and croaker (Otolithes ruber)
}

\author{
N. S. Sampath Kumar • R. A. Nazeer
}

Published online: 10 July 2012

(C) Springer-Verlag 2012

Erratum to: Mediterr J Nutr Metab

DOI 10.1007/s12349-011-0078-3

Due to neither scientific assistance nor contribution to the original publication of this article, one of the co-author's name is removed. The correct author group is listed below.

N. S. Sampath Kumar · R. A. Nazeer

The online version of the original article can be found under doi:10.1007/s12349-011-0078-3.

N. S. Sampath Kumar · R. A. Nazeer $(\square)$

Department of Biotechnology, School of Bioengineering,

SRM University, Kattankulathur, Chennai 603203,

Tamilnadu, India

e-mail: ra_nazeer@yahoo.com 